\title{
ANALISIS TRIWULANAN: Perkembangan Moneter, Perbankan dan Sistem Pembayaran, Triwulan II - 2011
}

\author{
Tim Penulis Laporan Triwulanan, Bank Indonesia
}

Rapat Dewan Gubernur (RDG) Bank Indonesia pada tanggal 12 Juli 2011 memutuskan untuk mempertahankan BI Rate pada level 6,75\%. Tingkat BI Rate tersebut dipandang masih sesuai dengan upaya untuk menjaga peningkatan kegiatan perekonomian yang disertai dengan stabilitas yang tetap terjaga, di tengah tingginya ekses likuiditas domestik dan masih derasnya aliran masuk modal asing. Ke depan, Bank Indonesia tetap mewaspadai potensi risiko tekanan terhadap stabilitas makroekonomi, khususnya yang berasal dari berlanjutnya aliran masuk modal asing dan tingginya harga komoditas global. Sementara itu, inflasi diperkirakan akan tetap terkendali dan dapat lebih rendah dari perkiraan sebelumnya apabila tidak ada perubahan kebijakan Pemerintah di bidang harga energi serta tetap terjaganya pasokan dan distribusi bahan pangan. Bank Indonesia akan terus menerapkan bauran kebijakan moneter dan kebijakan makroprudensial, dengan penekanan pada pengendalian likuiditas domestik, aliran masuk modal asing, dan apresiasi Rupiah yang sejalan dengan tren apresiasi nilai tukar di kawasan Asia. Bank Indonesia meyakini bahwa penerapan bauran kebijakan moneter dan makroprudensial tersebut mampu untuk menjaga stabilitas makro dan membawa inflasi kepada sasaran yang ditetapkan, yaitu 5\% $\%$ 1\% pada tahun 2011 dan 4,5\% $\%$ 1\% pada tahun 2012 .

Dewan Gubernur memandang bahwa pemulihan ekonomi global terus berlanjut, sebagaimana tercermin pada volume perdagangan dunia yang meningkat. Namun, prospek ekonomi global dibayangi sejumlah risiko, antara lain terkait krisis utang di Yunani, berakhirnya Quantitative Easing (QE) II oleh the Fed dan melambatnya ekonomi China. Risiko tersebut berpotensi menahan pertumbuhan ekonomi global pada tahun 2011, meskipun pemulihan ekonomi akan tetap meningkat pada tahun 2012. Sementara itu, harga komoditas global masih berada pada level yang tinggi meskipun terjadi koreksi pada harga minyak. Inflasi dunia juga secara umum meningkat, meskipun tekanan inflasi di emerging markets mereda. Respon kebijakan moneter di negara-negara emerging markets masih cenderung ketat, sementara di negara-negara maju masih cenderung akomodatif.

Di sisi domestik, Dewan Gubernur memprakirakan bahwa pertumbuhan ekonomi Indonesia dapat mencapai kisaran 6,3\%-6,8\% pada tahun 2011 dan 6,4\%-6,9\% pada tahun 
2012. Pertumbuhan ekonomi tersebut ditopang oleh sumber pertumbuhan yang semakin berimbang seiring dengan kinerja investasi yang terus meningkat dan kinerja ekspor yang masih tetap solid. Sementara itu, kinerja konsumsi rumah tangga juga tetap kuat. Pada triwulan III-2011, pertumbuhan ekonomi diprakirakan cukup tinggi, yaitu sebesar 6,6\%, ditopang oleh konsumsi dan investasi. Di sisi sektoral, seluruh sektor ekonomi diprakirakan akan tumbuh dengan baik. Sektor-sektor yang diprakirakan menjadi pendorong utama pertumbuhan ekonomi ke depan, antara lain sektor transportasi dan komunikasi; sektor perdagangan, hotel dan restoran; dan sektor industri.

Neraca Pembayaran Indonesia (NPI) untuk keseluruhan tahun 2011 diprakirakan masih mengalami surplus yang relatif besar. Hal ini seiring dengan masih kuatnya aliran masuk modal asing, termasuk dalam bentuk PMA, dan transaksi berjalan yang diperkirakan masih surplus meskipun mengalami penurunan. Penurunan surplus transaksi berjalan seiring dengan peningkatan impor terkait kenaikan permintaan domestik dan harga impor terutama migas. Di sisi transaksi modal dan finansial, aliran masuk modal asing diprakirakan masih berlanjut seiring dengan peningkatan kegiatan ekonomi domestik dan persepsi investor yang positif terhadap fundamental perekonomian Indonesia. Sejalan dengan itu, cadangan devisa pada akhir Juni 2011 tercatat sebesar 119,7 miliar dolar AS, atau setara dengan 6,8 bulan impor dan pembayaran utang luar negeri Pemerintah.

Pergerakan nilai tukar Rupiah diprakirakan tetap stabil dengan kecenderungan menguat, meskipun pada tingkat yang lebih terbatas, sejalan dengan berlanjutnya aliran masuk modal asing. Pada triwulan II-2011, nilai tukar Rupiah menguat 1,53\% (ptp) ke level Rp 8.577 per dolar AS dengan volatilitas yang tetap terjaga. Tren apresiasi nilai tukar Rupiah tersebut sejalan dengan upaya Bank Indonesia untuk meredam tekanan inflasi, khususnya dari imported inflation, dengan tetap mempertimbangkan dampaknya terhadap pertumbuhan ekonomi. Penguatan Rupiah yang terjadi masih sejalan dengan tren apresiasi mata uang di kawasan Asia sehingga sejauh ini tidak memberikan tekanan pada kinerja ekspor.

Tekanan inflasi sampai dengan triwulan II-2011 masih terkendali. Inflasi IHK pada triwulan II-2011 tercatat sebesar 0,36\% (qtq) sehingga secara tahunan turun menjadi 5,54\% (yoy), terutama didorong oleh deflasi di kelompok bahan pangan sementara inflasi inti meningkat secara terbatas. Inflasi inti tercatat 0,85\%(qtq) atau 4,63\%(yoy), didorong oleh kecenderungan tingginya harga komoditas global dan meningkatnya permintaan seiring kegiatan ekonomi yang meningkat. Inflasi kelompok administered prices relatif terbatas, yaitu sebesar 0,69\%(qtq), seiring dengan tidak adanya kebijakan pemerintah terkait harga energi. Sementara itu, kelompok bahan pangan mencatat deflasi -1,35\%(qtq), terutama disebabkan koreksi harga sejumlah komoditas pangan khususnya di bulan April dan Mei. Ke depan, inflasi diperkirakan akan tetap 
terkendali dan diperkirakan dapat lebih rendah dari perkiraan semula terutama apabila tidak ada kebijakan Pemerintah di bidang harga energi serta tetap terjaganya pasokan dan distribusi bahan pangan.

Stabilitas sistem perbankan tetap terjaga yang disertai terus membaiknya fungsi intermediasi perbankan dalam mendukung pembiayaan perekonomian. Stabilitas industri perbankan tercermin pada tingginya rasio kecukupan modal (CAR/Capital Adequacy Ratio) yang berada jauh di atas minimum $8 \%$ dan terjaganya rasio kredit bermasalah (NPL/Non Performing Loan) gross di bawah 5\%. Sementara itu, penyaluran kredit untuk pembiayaan kegiatan perekonomian terus berlanjut, tercermin pada pertumbuhan kredit yang pada Juni 2011 mencapai 23,4\%(yoy). Pertumbuhan kredit tertinggi terjadi pada kredit investasi yang sampai dengan bulan Mei 2011 tercatat sebesar 29,0\% (yoy). Bank Indonesia terus mendorong peningkatan efisiensi perbankan agar fungsi intermediasi dapat terus dioptimalkan dengan tetap menjaga stabilitas sistem perbankan secara keseluruhan

Di bidang sistem pembayaran, Bank Indonesia terus berupaya melakukan penyempurnaan untuk meningkatkan efektivitas dan efisiensi transaksi ekonomi. Saat ini Bank Indonesia mengembangkan BI-RTGS dan BI-SSSS Generasi II serta meningkatkan efisiensi pengelolaan rekening Pemerintah untuk meningkatkan kinerja infrastuktur sistem pembayaran. Bank Indonesia juga melanjutkan pembentukan National Payment Gateway (NPG) guna mencapai efisiensi nasional, serta melanjutkan implementasi standarisasi chip pada kartu ATM/Debit dan standarisasi uang elektronik guna meningkatkan keamanan instrumen pembayaran. Selain itu, Bank Indonesia melakukan penyesuaian kebijakan mengenai Penyelenggaraan Kegiatan Alat Pembayaran dengan Menggunakan Kartu, terutama mengenai kerjasama penyelenggara APMK dengan pihak lain, khususnya dalam pelaksanaan penagihan kartu kredit, serta mengetatkan persyaratan untuk memperoleh kartu kredit. Melalui penyempurnaan kebijakan ini, keamanan sistem pembayaran diharapkan dapat terus ditingkatkan. Sementara kebijakan pengedaran uang tetap ditujukan untuk mendukung ketersediaan uang rupiah dalam nominal yang cukup serta layak edar, serta meningkatkan layanan kas sehingga dapat menjangkau wilayah perbatasan dan daerah terpencil. Selain itu, Bank Indonesia juga menyempurnakan sistem dan prosedur layanan kas BI kepada perbankan. Melalui penyempurnaan tersebut, efektivitas dan efisiensi manajemen kas perbankan diharapkan dapat lebih ditingkatkan. 
halaman ini sengaja dikosongkan 